\title{
Ideal coronary stent: development, characteristics, and vessel size impact
}

\author{
Wzorcowy stent wieńcowy: rozwój, charakterystyka i wpływ średnicy naczynia \\ Janusz F. Dola (D), Beata Morawiec (D) , Piotr Muzyk , Ewa Nowalany-Kozielska (D), Damian Kawecki \\ 2nd Department of Cardiology, Faculty of Medical in Zabrze, Medical University of Silesia, Katowice, Poland
}

\begin{abstract}
The invasive treatment of coronary artery disease (CAD) has been a well-established therapeutic method for many years. Bare-metal stents (BMS), followed by subsequent generations of drug-eluting stent (DES) implantation in a narrowed coronary artery is the most effective treatment, especially in patients with acute coronary syndromes. Restenosis and stent thrombosis are the most important complications of this method. The long-term results of percutaneous coronary intervention (PCI) depend not only on the type of the implanted stent, operator skills, but also on the clinical characteristics of the patient, including the size of the treated vessel. In the era of DES, small vessels $(<3 \mathrm{~mm})$ proved to be one of the most important factors significantly worsening the clinical outcomes of PCI. Among the most important features of the stents available on the market, i.e. the type of drug released, the type of polymer and the strut thickness, the latter seems to be crucial, particularly for the treatment of small vessels.
\end{abstract}

\section{KEY WORDS}

coronary artery disease (CAD), bare-metal stent (BMS), drug-eluting stent (DES), percutaneous coronary interventions (PCI), vessel size

\section{STRESZCZENIE}

Inwazyjne leczenie choroby wieńcowej od wielu lat stanowi ugruntowaną metodę terapeutyczną. Implantacja najpierw stentów metalowych (BMS), a następnie kolejnych generacji stentów uwalniających leki (DES) w miejscu zwężonej tętnicy wieńcowej jest najskuteczniejszą metodą leczenia, zwłaszcza u pacjentów z ostrymi zespołami wieńcowymi. Restenoza i zakrzepica w stencie to główne powikłania tej metody. Wyniki odległe przezskórnej interwencji wieńcowej (PCI) zależą nie tylko od rodzaju implantowanego stentu, umiejętności operatora, lecz także od charakterystyki klinicznej pacjenta, w tym rozmiaru stentowanego naczynia. W erze stentów DES małe naczynia $(<3 \mathrm{~mm})$ okazały się jednym z najważniejszych czynników w istotny sposób pogarszających rezultaty kliniczne PCI. Spośród najistotniejszych cech dostępnych na rynku stentów, tj. rodzaju uwalnianego leku, typu polimeru oraz grubości przęseł, ta ostatnia wydaje się kluczowa, szczególnie w przypadku leczenia małych naczyń.

\section{SŁOWA KLUCZOWE}

choroba wieńcowa (CAD), stent metalowy (BMS), stent uwalniający lek (DES), przezskórne interwencje wieńcowe (PCI), rozmiar naczynia 


\section{INTRODUCTION}

The invasive treatment of coronary artery disease (CAD) has been a well-established therapeutic method for many years. Percutaneous coronary intervention (PCI), has developed over years regarding the type of stent, the technique of the procedure and adoption to clinical settings. The long-term results of PCI also depend on the angiographic and in-situ characteristics of the treated lesion, including the size of the vessel.

\section{Historical perspective}

The beginning of interventional cardiology in terms of CAD dates back to 1977 when Andreas Grüntzig, a German physician who lived in Zurich, for the first time applied a balloon-tipped catheter to perform angioplasty in a conscious patient with significant left anterior descending artery stenosis. Despite the excellent immediate and long-term outcomes, an increasing number of plain old balloon angioplasty (POBA) procedures revealed the problem of so-called restenosis, i.e. a recurrence of stenosis in the dilated part of the vessel. This complication was observed even in 30-50\% of patients. In addition, approximately $3 \%$ of patients presented with myocardial infarction secondary to acute occlusion of the artery $[1,2,3,4]$. The clinical application of the concept of stent implanting dating back to 1964 was not undertaken until 1986, when the self-expanding woven mesh stent (Wallstent) was used for the first time (Schneider) [5]. Soon other structures appeared on the market - the first two stents, the use of which was approved in 1994 by the Food and Drug Administration (FDA) included the Palmaz-Schatz Stent (Johnson \& Johnson) and Gianturco-Roubin Flex Stent (The Cook Inc.) [6]. Two large multicenter randomized clinical trials (STRESS and BENESTENT) showed (based on the Palmaz-Schatz stent) that the new technology allowed restenosis to be reduced by $20-30 \%$ compared to POBA $[7,8]$. This success, however, was soon overshadowed by subacute stent thrombosis in even $18 \%$ of patients. Initially, attempts were made to address this problem using aggressive anticoagulant treatment with vitamin $\mathrm{K}$ antagonists, which resulted in further complications (i.e. bleeding). Soon, there was even a temporary suspension of the routine use of stents that were applied only in the case of balloon angioplasty failure. At that stage, many cardiologists predicted the early end of this technology.

The safety of percutaneous angioplasty with stent implantation was restored by Prof. Colombo, who postulated for the first time the replacement of warfarin with ticlopidine, prepared some form of instruction describing the methodology of proper stent implantation (still valid until today) and drew attention to the absolute necessity for the use of high pressure balloon inflation during stent implantation (min. 14-18 atm), which was confirmed by intravascular ultrasound technology that was revolutionary at that time [9]. A similar opinion was shared by Prof. Serruys in the paper with the con- troversial title: "Who was thrombogenic: The stent or the doctor?" [10].

\section{First-generation des}

In the case of bare-metal stents (BMS), including the most studied cobalt-chromium Multi-Link Vision (Abbott), there was still a concern about repeat revascularization. Restenosis was still found in 15-30\% of patients. Studies on the etiopathogenesis showed that it was caused by excessive neointimal proliferation in response to periprocedural vascular wall injury followed by inflammatory response $[11,12]$. As a result, interventional cardiologists were soon provided with a new tool - antiproliferative drug-eluting stents (DES). They were aimed at improving the efficacy of the percutaneous treatment of CAD. And indeed, during the first period of their application (i.e. from the publication of the results of the RAVEL trial in 2001 to the World Congress of Cardiology in Barcelona in 2006), it seemed that the new technology met the challenges. Taxus (Boston Scientific) and Cypher (Cordis) were the precursors of DES. They were structures made of $316 \mathrm{~L}$ stainless steel with a strut thickness of $132-140 \mu \mathrm{m}$ coated with a durable, non-biocompatible polymer matrix that provided a controlled release of the drug, i.e. anti-cancer paclitaxel (Taxus; PES) and sirolimus (Cypher; SES), that is an immunosuppressive macrolide antibiotic. The aim of these agents was to delay the "healing" of the vessel after stent implantation, and thus to prevent endothelial cell proliferation as the cause of restenosis by inhibiting the migration of smooth muscle cells toward the endothelium and disruption of the cell cycle. The clinical benefits of DES were shown in the TAXUS-IV study which found that restenosis occurred in $26.6 \%$ of patients with implanted BMS in a 9-month follow-up, while this percentage was only $7.9 \%$ in the group of patients after PES implantation $[13,14]$.

Unexpectedly, the World Congress of Cardiology in Barcelona in 2006 with the speech of Professor Camenzind brought doubts regarding DES safety. Some alarming data were presented, according to which the number of myocardial infarctions and coronary angioplasty-related deaths was higher in the group of sirolimus-eluting stents (SES) $(6.3 \%)$ compared to BMS $(3.9 \%)$ [15]. The BASKET-LATE study confirmed an increase in major adverse cardiac events (MACE) after 7 to 18 months following DES implantations compared to BMS implantation [16]. The results of a series of studies and meta-analyses confirming this trend were soon published. Nonetheless, the discrepancies were related to the statistical significance of endpoints such as the overall mortality, cardiac mortality, and non-fatal myocardial infarction $[17,18,19,20,21]$. Thrombosis and its clinical consequences received a great deal of attention not only in the medical community, but also among patients. In American public media, DES were even compared to "tiny time bombs" [22].

Both Cypher and Taxus stents were approved by the FDA based on randomized clinical trials with a short 
follow-up. Reevaluation of the safety of DES was carried out in 2006, by an FDA-appointed panel of 21 experts [23]. Considering a new definition of stent thrombosis developed by the Academic Research Consortium (ARC), attention was drawn to the necessity of continuing dual antiplatelet therapy consisting of acetylsalicylic acid and a platelet adenosine diphosphate receptor antagonist (Dual Antiplatelet Therapy; DAPT) for 12 months in patients with a low risk of bleeding (a 6-month DAPT period in the BASKET-LATE study). The implantation of DES in accordance with the manufacturer's recommendations ("on-label") was safe, while a higher risk of DES thrombosis in "off-label" cases ( $60 \%$ of DES use) was not associated with an increased risk of death or myocardial infarction compared to BMS [24].

\section{Second-generation des}

Due to the high heterogeneity of the clinical effects of the implantation of DES vs. BMS characterizing the ideal stent is challenging. From the clinical perspective, it should fulfill the criteria of high efficacy (low percentage of restenosis), and high safety (low thrombogenicity). From the procedural perspective, emphasis should be placed on easy delivery to the treated segment of the vessel. After introducing drug elution and DAPT, it was soon confirmed that thrombosis was the result of delayed stent strut endothelialization owing to antiproliferative drugs released by DES and a proinflammatory effect of the polymer $[25,26,27]$. As a result, the release of new drugs, a thinner strut platform as well as biocompatible, biodegradable polymers or even no polymer were introduced. The so-called second-generation DES, such as Endeavor/Resolute (Medtronic) releasing zotarolimus (ZES), and Xience (Abbott) releasing everolimus (EES) were approved for use as early as in 2008. The steel structure of first-generation DES was replaced by a cobalt-chromium structure with a significantly reduced stent strut thickness (81-91 $\mu \mathrm{m})$, which was coated with a thinner, durable biocompatible polymer (durable-polymer DES; DP-DES). Comparisons of the long-term effects after Xience stent implantation (EES) vs. Taxus stent implantation (PES) showed the advantage of Xience in reducing overall mortality as well as improvement in individual safety and efficacy parameters $[28,29]$. In a 3 -year follow-up, possible and definite stent thrombosis was reported in $1.4 \%$ of patients after EES implantation compared to $4.9 \%$ after PES implantation $[28,29]$. This was also confirmed by numerous large registers. The risk of very late stent thrombosis in the EES group decreased by $76 \%$ compared to PES and by $67 \%$ compared to SES [30]. Similar conclusions were also observed based on the Swedish SCAAR registry (about 95000 patients) in which the percentage of restenosis decreased by $38 \%$, the percentage of stent thrombosis decreased by $43 \%$ and the risk of death decreased by $23 \%$ in the case of second-generation DES compared to first-generation DES [31]. The structures (ZES Resolute and EES Xience) provided similar long-term clinical results when they were directly compared $[32,33,34]$. BMS and first-generation DES were completely supplanted by second-generation DES which became the treatment of choice for stable CAD and acute coronary syndromes. This was confirmed by the ESC guidelines (2012) on the management of ST-segment elevation myocardial infarction (STEMI), which recommended the use of DES during primary PCI as the preferred method in relation to BMS implantation (Recommendation Class IIa) [35].

\section{Third-generation des}

Another milestone in the development of stents was related to DES with a biodegradable polymer and polymer-free stents (referred to as third-generation DES) following the assumption that the polymer was responsible for maintaining the inflammatory process within the vessel wall and delayed stent strut endothelization crucial to restenosis and stent thrombosis [36,37]. Biodegradable polymer DES (BP-DES) appeared on the market and included Orsiro (Biotronik), Nobori (Terumo), Synergy (Boston Scientific) and Biomatrix (Biosensors International), followed by polymer-free DES (PF-DES) such as Coroflex ISAR (B. Braun), BioFreedom (Biosensors International) and Cre8 (Alvimedica). Stents based on a biodegradable polymer were the subjects of many prospective and retrospective observations. The Nobori stent did not achieve better safety or efficacy parameters compared to the Xience stent in a 5-year follow-up [38]. In turn, the Synergy stent, in which the everolimus-eluting biodegradable polymer is located only on the side of the vessel wall (abluminally) and the surface of the strut exposed to the blood stream is in essence a BMS, unexpectedly caused more acute stent thrombosis compared to the Xience stent $(1.2 \%$ vs. $0.3 \% ; p=0.032)[39,40]$. Similar conclusions were also found in other studies $[41,42,43]$ and meta-analyses $[44,45]$. BP-DES did not contribute to a reduction in adverse clinical events compared to new-generation DP-DES, which are distinguished by the most favorable efficacy-to-safety ratio among all DES available on the market. This is particularly visible in the case of the Xience stent. In addition, BP-DES do not allow shortening of DAPT compared to new-generation DP-DES due to a worse safety profile than new-generation DP-DES during the first year after implantation. It is known that polymers which require active reabsorption significantly increase the local inflammation of the vessel wall compared to durable polymers $[46,47]$. In turn, in-vitro studies showed that a durable fluorinated copolymer (used e.g. in Xience and Promus stents) activated platelets to a lesser extent compared to other polymers $[48,49]$ or even the uncoated metal surface of the stent, which had a thrombo-protective effect [50]. The concept of DES with no polymer resulted in the release of the BioFreedom polymer-free biolimus-eluting stent (PF-BES), which was characterized by an increased percentage of restenosis compared to DP-EES in an 18-month follow-up. However, after applying the propensity-score-matching method, the above trend lost statistical significance. No differences were reported in 
terms of safety [51]. Nevertheless, in the case of this device the possibility of shortening DAPT to 1 month after stent implantation in stable CAD in patients with an increased bleeding risk (IIb) according to the 2017 ESC guidelines should be underlined [52]. Another polymer-free sirolimus- and probucol-eluting stent (Coroflex ISAR) did not improve the safety or efficacy parameters as compared to DP-ZES (Resolute) in a one-year follow-up [53].

\section{Size of treated vessel. Stent strut thickness}

In the era of first-generation DES, many comparisons were made between them and BMS. Detailed analyses in patient subgroups demonstrated that in large coronary arteries $(>3 \mathrm{~mm})$ the advantage of first-generation DES in reducing the percentage of restenosis in relation to BMS was lower than in the case of small vessels $[54,55,56,57]$. Moreover, several registries showed that first-generation DES implantation in large vessels resulted in an increased prevalence of adverse events secondary to stent thrombosis, i.e. fatal myocardial infarction over a 6-month follow-up [56,58]. An inverse relationship was observed in the case of small vessels $(<3 \mathrm{~mm})$ where the DES anti-restenotic potential was so significant that it outweighed all the DES-related disadvantages in terms of safety $[56,59,60,61]$. Moreover, the clinical presentation of stent thrombosis depends on the vessel size. In the case of large vessels, stent thrombosis often results in myocardial infarction or even death, while it may remain clinically silent in small vessels. In a large prospective study comparing the clinical and angiographic results after implantation of first-generation DES, i.e. SES-Cypher vs. PES-Taxus, Elezi et al. observed that the size of the treated vessel $<2.41 \mathrm{~mm}$ was an independent risk factor for restenosis. A statistically significant advantage in terms of target lesion revascularization (TLR) in favor of SES $(8.6 \%$ for SES vs. $16.4 \%$ for PES; $p=0.002$ ) was also observed only in the small vessel subgroup $(<2.41 \mathrm{~mm})$ Furthermore, the size of the vessel did not affect the risk of myocardial infarction or death in patients undergoing SES or PES implantation [62]. Similar results were also obtained by other researchers $[63,64]$.

After new-generation DES restored an acceptable level of safety to PCI, the efficacy of this method was again scrutinized. It was observed that in some groups of patients (sometimes referred to in Anglo-Saxon literature as "challenging"), the clinical outcomes were still worse than in the general population. A cohort of patients with CAD in small vessels is one of such groups. The treatment of lesions in small vessels has always been a challenge for interventional cardiology $[65,66,67,68,69]$. The DUTCH PEERS study (TWENTE II) showed that a subgroup of patients undergoing PCI with second-generation DES (DP-EES or DP-ZES) at least in one vessel with a diameter smaller than $2.5 \mathrm{~mm}$ had worse prognosis compared to patients in whom such revascularization was not required (target lesion failure - TLF 9.5\% vs. 5.4\%; P log rank
$=0.001)$ as indicated in a 2-year follow-up [70]. In the pooled analysis comparing PCI with first-generation DES (PES) and second-generation DP-EES in a 2-year follow-up, the percentage of MACE was significantly higher in the subgroup of PCI in vessels with a diameter $\leq 2.65 \mathrm{~mm}$ and/or with a length $>13.4 \mathrm{~mm}$ compared to PCI in short lesions in large vessels. Of note, the prevalence of thrombosis after DP-EES implantation was low and was independent from the complexity of the lesion [71].

Second-generation DES appeared on the market more than 10 years ago. It seemed that the plateau was achieved in which most of the available structures provided good and comparable results crucial for the prognosis with slight DP-EES supremacy. In 2019, the results of two multicenter prospective trials were reported, both showing the advantage of BP-SES (Orsiro) over DP-ZES (Resolute Integrity): the first in terms of revascularization of the same target lesion in small vessels $(<2.5 \mathrm{~mm})$ with a lower rate of TLR in favor of Orsiro in a one-year follow-up $(2.1 \%$, vs. $5.3 \%$, respectively, $\mathrm{p}=0.009$ ) [72]; and the second, in primary angioplasty in STEMI, TLF was significantly less prevalent after BP-SES Orsiro implantation compared to DP-EES Xience (4\% vs. 6\%) [73]. Similar conclusions were observed later on [74]. Thinner stent struts (Orsiro - strut thickness dependent on the stent diameter: $60 \mu \mathrm{m}$ for 2.25-3.0 mm diameter sizes and $80 \mu \mathrm{m}$ for $3.5-4.0 \mathrm{~mm}$, Synergy $-71 \mu \mathrm{m}$, Xience and Promus $-81 \mu \mathrm{m}$, Resolute Integrity $-91 \mu \mathrm{m}$ ) are related to a smaller footprint within the artery, which is associated with reduced wall damage, reduced local inflammation and hence the promotion of healing, which is crucial for the prevention of excessive endothelial proliferation and stent thrombosis $[75,76]$. Thinner stent struts are also related to a lower percentage of occluded collateral vessels, which has a direct impact on a reduction in the number of periprocedural myocardial infarctions, mostly observed after anterior descending artery revascularization (multiple small septal and oblique branches, large vascular area) $[74,77,78]$. Studies using new visualization technologies, such as three-dimensional intravascular ultrasound (3D-IVUS) and computational fluid dynamics (CFD) allowed better understanding of the etiology of adverse postprocedural clinical events. It had been previously reported that the thickness of the stent struts had a key influence on the extent of blood flow disorders in the stented vessel $[79,80,81,82,83]$.

The introduction of a fully bioresorbable scaffold (BVS) Absorb (Abbott) with a strut thickness of up to $157 \mu \mathrm{m}$, which was the first representative of fourth-generation DES, was disappointing and eventually resulted in its withdrawal from the market. It was due to an increased incidence of myocardial infarction in the revascularized vessel (TV-MI 6\% vs. $1 \% ; p=0.011$ ) and more prevalent stent thrombosis $(2.3 \%$ vs. $0.7 \%, p=0.01)$ in a 3-year follow-up compared to DP-EES Xience. It was also demonstrated that a small vessel diameter $(<2.25 \mathrm{~mm})$ was an independent risk factor for TLF 
$[84,85]$. However, extensive work is being continued on further development of the promising bioresorbable scaffold technology.

\section{CONCLUSIONS}

To conclude, revascularization with first-generation DES was associated with a lower risk of restenosis, but with a higher risk of late stent thrombosis compared to BMS. Second- and third-generation DES significantly improved the long-term efficacy and safety in comparison to first-generation DES and BMS [86]. Based on the 15 years of experience in treating patients with DES, the strut thickness seems to have the greatest impact on the clinical outcomes, particularly in PCI for lesions in small vessels.

The development of interventional cardiology in terms of CAD is related to a further decrease in strut thickness [87] and improvement in the bioresorbable scaffold (BVS) $[88,89]$.

\section{Author's contribution}

Study design - D. Kawecki, B. Morawiec, J.F. Dola

Literature research - J.F. Dola, P. Muzyk

Writing the draft of the manuscript - J.F. Dola

Critical review of the manuscript - E. Nowalany-Kozielska, D. Kawecki

\section{REFERENCE}

1. Kardiologia Interwencyjna. Red. nauk. G. Brzezińska-Rajszys, M. Dąbrowski, W. Rużyłł, A. Witkowski. Wydawnictwo Lekarskie PZWL. Warszawa 2009 , s. $27-31$

2. Moscucci M. Grossman \& Baim's Cardiac Catheterization, Angiography, and Intervention. 7th Edition. Lippincott Williams \& Wilkins. Philadelphi 2006, s. 76-79.

3. Cardiovascular Catheterization and Intervention: A Textbook of Coronary, Peripheral, and Structural Heart Disease. Ed. D. Mukherjee, E. Bates, M. Roffi, D. Moliterno. CRC Press. Texas 2010, s. 173-194.

4. Cardiac catheterization and percutaneous interventions. Ed. I. Kay, M. Sabate, M. Costa. Taylor \& Francis Group. London 2004, s. 16-44, doi org $/ 10.3109 / 9780203494837$.

5. Carrié D., Elbaz M., Andrieu M., Cantié P., Fourcade J., Puel J. Ten-year clinical and angiographic follow-up of coronary wallstent. Am. J. Cardiol. 2000; 85(1): 95-98, doi:10.1016/S0002-9149(99)00613-X

6. Butany J., Carmichael K., Leong S.W., Collins M.J. Coronary artery stents identification and evaluation. J. Clin. Pathol. 2005; 58(8): 795-804, doi: 10.1136/jcp.2004.024174.

7. Fischman D.L., Leon M.B., Baim D.S., Schatz R.A., Savage M.P., Penn I., Detre K., Veltri L., Ricci D., Nobuyoshi M. et al. A randomised compariso of coronary-stent placement and balloon angioplasty in the treatment of coronary artery disease. N. Engl. J. Med. 1994; 331(8): 496-501, doi: 10.1056/ NEJM199408253310802

8. Serruyes P.W., de Jaegere P., Kiemeneij F., Macaya C., Rutsch W., Heyndrickx G., Emanuelsson H., Marco J., Legrand V., Materne P. et. al. A comparison of balloon expandable-stent implantation with balloon angioplasty in patients with coronary artery disease. On behalf of the Benestent Study Group. N. Engl. J. Med. 1994; 331(8): 489-495, doi: 10.1056/NEJM199408253310801. 9. Moussa I., Di Mario C., Di Francesco L., Reimers B., Blengino S., Colombo A. Subacute stent thrombosis and the anticoagulation controversy: Changes in drug therapy, operator technique, and the impact of intravascular ultrasound. Am. J. Cardiol. 1996; 78(3 A): 13-17, doi: 10.1016/S0002-9149(96)00486-9.

10. Serruys P.W., Di Mario C. Who was thrombogenic: The stent or the doctor? Circulation 1995; 91(6): 1891-1893, doi: 10.1161/01.CIR.91.6.1891. 11. Hoffmann R., Jansen C., Konig A., Haager P.K., Kerckhoff G., vom Dahl J., Klauss V., Hanrath P., Mudra H. Stent design related neointimal tissue proliferation in human coronary arteries; an intravascular ultrasound study. Eur. Heart J. 2001; 22(21): 2007-2014, doi: 10.1053/euhj.2001.2606.

12. Handbook of coronary stents. Ed. P.W. Serruys, B. Rensing. CRC Press. London 2001, s. 34-60.

13. Cheng-Lai A., Frishman W.H. Sirolimus-eluting coronary stents: novel devices for the management of coronary artery disease. Am. J. Ther. 2004; 11(3): 218-228, doi: $10.1097 / 00045391-200405000-00011$.

14. Halkin A., Stone G.W. Polymer-based paclitaxel-eluting stents in percutaneous coronary intervention: a review of the TAXUS trials. J. Interv. Cardiol. 2004; 17(5): 271-282, doi: 10.1111/j.1540-8183.2004.04040.x.

15. Camenzind E., Steg P.G., Wijns W. Stent thrombosis late after implantation of first-generation drug-eluting stents: a cause for concern. Circulation 2007 115(11): 1440-1455, doi: 10.1161/CIRCULATIONAHA.106.666800.

16. Pfisterer M., Brunner-La Rocca H.P., Buser P.T., Rickenbacher P., Hunzike P., Mueller C., Jeger R., Bader F. Osswald S., Kaiser C. Late clinical events after clopidogrel discontinuation may limit the benefit of drug-eluting stents: an observational study of drug-eluting versus bare-metal stents. J. Am. Coll Cardiol. 2006; 48(12): 2584-2591, doi: 10.1016/j.jacc.2006.10.026.
17. Nordmann A.J., Briel M., Bucher H.C. Mortality in randomized controlled trials comparing drug-eluting vs. bare metal stents in coronary artery disease: a meta-analysis. Eur. Heart J. 2006; 27(23): 2784-2814, doi: 10.1093/eurheartj/ ehl282.

18. Baim D.S., Mehran R., Kereiakes D.J., Gross T.P., Simons M., Malenka D., Kaplan A.V. Postmarket Surveillance for Drug-Eluting Coronary Stents. A Comprehensive Approach. Circulation 2006; 113: 891-897, doi: 10.1161/ circulationaha.105.569657.

19. Mauri L., Hsieh W.H., Massaro M., Ho K.K., D’Agostino R., Cutlip D.E. Stent thrombosis in randomized clinical trials of drug-eluting stents. N. Engl. J. Med. 2007; 356(10): 1020-1029, doi: 10.1056/NEJMoa067731.

20. Stettler C., Wandel S., Allemann S., Kastrati A., Morice M.C., Schömig A., Pfisterer M.E., Stone G.W., Leon M.B., Suarez de Lezo J., Goy J.J. et al. Outcomes associated with drug-eluting and bare-metal stents: a collaborative network meta-analysis. Lancet 2007; 370(9591): 937-948, doi: 10.1016/ S0140-6736(07)61444-5

21. Lagerqvist B., James S.K., Stenestrand U., Lindbäck J., Nilsson T., Wallentin L. Long-term outcomes with drug-eluting stents versus bare-metal stents in Sweden. N. Engl. J. Med. 2007; 356(10): 1009-1019, doi: 10.1056/NEJMoa067722.

22. Bazell R. Millions face risk from drug-coated stents. NBC News. 2007. http://www.nbcnews.com/id/15816251/ns/health-heart health/t/millions-facerisk-drug-coated-stents/\#.XjoXTNThA1J [dostęp: 18.05.2020].

23. Cutlip D.E., Windecker S., Mehran R., Boam A., Cohen D.J., van Es G.A., Steg P.G., Morel M.A., Mauri L., Vranckx P., McFadden E. et al. Clinical end points in coronary stent trials: a case for standardized definitions. Circulation 2007; 115(17): 2344-2351, doi: 10.1161/CIRCULATIONAHA.106.685313. 24. Boam A. Update to FDA Statement on Coronary Drug-Eluting Stents. U.S. Department of Health and Human Services. Food and Drug Administration. 2008

25. Kotani J., Awata M., Nanto S., Uematsu M., Oshima F., Minamiguchi H., Mintz G.S., Nagata S. Incomplete neointimal coverage of sirolimus-eluting stents: angioscopic findings. J. Am. Coll. Cardiol. 2006; 47(10): 2108-2111, doi: 10.1016/j.jacc.2005.11.092

26. Finn A.V., Joner M., Nakazawa G., Kolodgie F., Newell J., John M.C., Gold H.K., Virmani R. Pathological correlates of late drug-eluting stent thrombosis: strut coverage as a marker of endothelialization. Circulation 2007; 115(18): 2435-2441, doi: 10.1161/CIRCULATIONAHA 107.693739

27. Daemen J., Wenaweser P., Tsuchida K., Abrecht L., Vaina S., Morger C., Kukreja N., Jüni P., Sianos G., Hellige G., van Domburg R.T. et al. Early and late coronary stent thrombosis of sirolimus-eluting and paclitaxel-eluting stents in routine clinical practice: data from a large two-institutional cohort study. Lancet 2007; 369(9562): 667-678, doi: 10.1016/S0140-6736(07)60314-6.

28. Gada H., Kirtane A.J., Newman W., Sanz M., Hermiller J.B., Mahaffey K.W., Cutlip D.E., Sudhir K., Hou L., Koo K., Stone G.W. 5-year results of a randomized comparison of XIENCE V everolimus-eluting and TAXUS paclitaxel-eluting stents: final results from the SPIRIT III trial (clinical evaluation of the XIENCE V everolimus eluting coronary stent system in the treatment of patients with de novo native coronary artery lesions). JACC Cardiovasc. Interv. 2013; 6(12): 1263-1266, doi: 10.1016/j.jcin.2013.07.009.

29. Kedhi E., Joesoef K.S., McFadden E., Wassing J., van Mieghem C., Goedhart D., Smits P.C. Second-generation everolimus-eluting and paclitaxel-eluting stents in real-life practice (COMPARE): a randomised trial. Lancet 2010; 375(9710): 201-209, doi: 10.1016/S0140-6736(09)62127-9. 
30. Räber L., Magro M., Stefanini G.G., Kalesan B., van Domburg R.T., Onuma Y, Wenaweser P., Daemen J., Meier B., Jüni P., Serruys P.W., Windecker S. Very late coronary stent thrombosis of a newer-generation everolimus-eluting stent compared with early-generation drug-eluting stents: a prospective cohor study. Circulation 2012; 125(9): 1110-1121, doi: /10.1161/CIRCULATIONAHA. 111.058560 .

31. Sarno G., Lagerqvist B., Fröbert O., Nilsson J., Olivecrona G., Omerovic E., Saleh N., Venetzanos D., James S. Lower risk of stent thrombosis and restenosis with unrestricted use of 'new-generation' drug-eluting stents: a report from the nationwide Swedish Coronary Angiography and Angioplasty Registry (SCAAR). Eur. Heart J. 2012; 33(5): 606-613, doi: 10.1093/eurheartj/ehr479. 32. Silber S., Windecker S., Vranckx P., Serruys P.W. Unrestricted randomise use of two new generation drug-eluting coronary stents: 2-year patient-related versus stent-related outcomes from the RESOLUTE All Comers trial. Lance 2011; 377(9773): 1241-1247, doi: 10.1016/S0140-6736(11)60395-4.

33. Tandjung K., Sen H., Lam M.K., Basalus M.W., Louwerenburg J.H., Stoel M.G., van Houwelingen K.G., de Man F., Linssen G.C.M., Saï S.A.M., Nienhuis M.B. et al. Clinical outcome following stringent discontinuation of dual antiplatelet therapy after 12 months in real-world patients treated with econd-generation zotarolimus-eluting resolute and everolimus-eluting Xience V stents: 2-year follow-up of the randomized TWENTE Trial. J. Am. Coll. Cardiol. 2013; 61: 2406-2416, doi: 10.1016/j.jacc.2013.04.005.

34. Taniwaki M., Stefanini G.G., Silber S., Richardt G., Vranckx P., Serruys P.W., Buszman P.E., Kelbaek H., Windecker SRESOLUTE All-Comers Investigators. 4-year clinical outcomes and predictors of repeat revascularization in patients treated with new-generation drug-eluting stents: a report from the RESOLUTE All-Comers trial (A Randomized Comparison of a Zotarolimus-Eluting Stent With an Everolimus-Eluting Stent for Percutaneous Coronary Intervention). J. Am. Coll. Cardiol. 2014; 63(16): 1617-1625, doi: 10.1016/j. jacc. 2013.12 .036

35. Steg P.G., James S.K., Atar D., Badano L.P., Blömstrom-Lundqvist C., Borger M.A., Di Mario C., Dickstein K., Ducrocq G., Fernandez-Aviles F. Gershlick A.H. et al. ESC Guidelines for the management of acute myocardia infarction in patients presenting with ST-segment elevation: The Task Force on the management of ST-segment elevation acute myocardial infarction of the European Society of Cardiology (ESC). Eur. Heart J. 2012; 33: 2569-2619, doi 10.1093/eurheartj/ehs215.

36. Muramatsu T., Onuma Y., Zhang Y.J., Bourantas C.V., Kharlamov A., Diletti R., Farooq V., Gogas B.D., Garg S., García-García H.M., Ozaki Y., Serruys P.W. Progress in treatment by percutaneous coronary intervention: the stent of the future. Rev. Esp. Cardiol. (Engl. Ed). 2013; 66(6): 483-496, doi: 10.1016/j. rec.2012.12.009.

37. Thakkar A.S., Dave B.A. Revolution of drug-eluting coronary stents: an analysis of market leaders. Eur. Med. J. 2016; 1(4): 114-125.

38. Smits P.C., Hofma S., Togni M., Vázquez N., Valdés M., Voudris V., Slag boom T., Goy J.J., Vuillomenet A., Serra A., Nouche R.T. et al. Abluminal biodegradable polymer biolimus-eluting stent versus durable polymer everolimuseluting stent (COMPARE II): a randomised, controlled, non-inferiority trial. Lancet 2013; 381 (9867): 651-660, doi: 10.1016/S0140-6736(12)61852-2. 39. Zanchin C., Ueki Y., Zanchin T., Häner J., Otsuka T., Stortecky S., Koskina K.C. , Siontis G.C.M., Praz F., Moschovitis A., Hunziker L. et al. Everolimuseluting biodegradable polymer versus everolimus-eluting durable polymer stent for coronary revascularization in routine clinical practice. J. Am. Coll. Cardiol. Intv. 2019; 12(17): 1665-1675, doi: 10.1016/j.jcin.2019.04.046. 40. Zanchin C., Yasushi U., Zanchin T. Everolimus-Eluting Biodegradable Polymer Versus Everolimus-Eluting Durable Polymer Stent for Coronary Revascularization in Routine Clinical Practice. JACC 2019; 12(17): 1665-1675, doi. org/10.1016/j.jcin.2019.04.046.

41. Meredith I.T., Verheye S., Dubois C.L., Dens J., Fajadet J., Carrié D., Wals S., Oldroyd K.G., Varenne O., El-Jack S., Moreno R. et al. Primary endpoin results of the EVOLVE trial: a randomized evaluation of a novel bioabsorbable polymer-coated, everolimus-eluting coronary stent. J. Am. Coll. Cardiol. 2012; 59(15): 1362-1370, doi: 10.1016/j.jacc.2011.12.016

42. Christiansen E.H., Jensen L.O., Thayssen P., Tilsted H.H., Krusell L.R Hansen K.N., Kaltoft A.K., Maeng M., Kristensen S.D., Bøtker H.E, Terkelsen C.J. et al. For the Scandinavian Organization for Randomized Trials with Clinical Outcome (SORT OUT) V Investigators. Biolimus-eluting biodegradable polymer-coated stent versus durable polymer-coated sirolimus-eluting stent in unselected patients receiving percutaneous coronary intervention (SORT OUT V): a randomised non-inferiority trial. Lancet 2013 ; 381: 661-669, doi: 10.1016/ S0140-6736(12)61962-X.

43. Windecker S., Serruys P.W., Wandel S., Buszman P., Trznadel S., Linke A., Lenk K., Ischinger T., Klauss V., Eberli F., Corti R. et al. Biolimus-eluting stent with biodegradable polymer versus sirolimus-eluting stent with durable polymer for coronary revascularisation (LEADERS): a randomised noninferiority trial. Lancet 2008; 372 (9644): 1163-1173, doi: 10.1016/S01406736(08)61244-1.

44. Bangalore S., Toklu B., Amoroso N., Fusaro M., Kumar S., Hannan E.L. Faxon D.P., Feit F. Bare metal stents, durable polymer drug eluting stents, and biodegradable polymer drug eluting stents for coronary artery disease: mixed treatment comparison meta-analysis. BMJ 2013; 347: f6625, doi: 10.1136/bmj. f6625.
45. Palmerini T., Biondi-Zoccai G., Della Riva D., Mariani A., Sabaté M., Smits P.C., Kaiser C., D'Ascenzo F., Frati G., Mancone M., Genereux P., Stone G.W. Clinical outcomes with bioabsorbable polymer-versus durable polymer-based drug-eluting and bare-metal stents: evidence from a comprehensive network meta-analysis. J. Am. Coll. Cardiol. 2014; 63(4): 299-307, doi: 10.1016/j. jacc.2013.09.061.

46. De Scheerder I.K., Wilczek K.L., Verbeken E.V. et al. Biocompatibility of biodegradable and nonbiodegradable polymer-coated stents implanted in porcine peripheral arteries. Cardiovasc. Intervent. Radiol. 1995; 18: 227-232.

47. van der Giessen W.J., Lincoff A.M., Schwartz R.S., van Beusekom H.M., Serruys P.W., Holmes Jr D.R., Ellis S.G., Topol E.J. Marked inflammatory sequelae to implantation of biodegradable and nonbiodegradable polymers in porcine coronary arteries. Circulation 1996; 94(7): 1690-1697, doi: 10.1161/01. cir.94.7.1690.

48. Chinn J.A., Sauter J.A., Phillips Jr R.E., Kao W.J., Anderson J.M., Hanson S.R., Ashton T.R. Blood and tissue compatibility of modified polyester: thrombosis, inflammation, and healing. J. Biomed. Mater Res. 1998; 39(1): 130-140, doi: 10.1002/(sici)1097-4636(19980101)39:1<130::aid-jbm15>3.0.co; 2-j.

49. Liu T., Lin W., Huang L., Chen S., Yang M. Surface characteristics and hemocompatibility of PAN/PVDF blend membranes. Polym. Adv. Technol. 2005; 16(5): 413-419, doi: 10.1002/pat.592.

50. Kolandaivelu K., Swaminathan R., Gibson W.J., Kolachalama V.B., Nguyen-Ehrenreich K.L., Giddings V.L., Coleman L., Wong G.K., Edelman E.R. Stent thrombogenicity early in high-risk interventional settings is driven by stent design and deployment and protected by polymer-drug coatings. Circulation 2011; 123(13): 1400-1409, doi: 10.1161/CIRCULATIONAHA.110.003210.

51. Pepe M., Biondi-Zoccai G., Corcione N., Nestola P.L., Ferraro P., Morello A. Conte S., Prati F., Bianchi F.P, Bortone A.S., Giordano A. Comparative effectiveness and safety of polymer-free biolimus-eluting stent and durable polymer everolimus-eluting stent in all-comer patients who underwent percutaneous coronary interventions. Am. J. Cardiol. 2019; 124(2): 195-204, doi: 10.1016/j. amjcard.2019.04.015.

52. Valgimigli M., Bueno H., Byrne R.A., Collet J.P., Costa F., Jeppsson A., Jüni P., Kastrati A., Kolh P., Mauri L., Montalescot G. 2017 ESC focused update on dual antiplatelet therapy in coronary artery disease developed in collaboration with EACTS: The Task Force for dual antiplatelet therapy in coronary artery disease of the European Society of Cardiology (ESC) and of the European Association for Cardio-Thoracic Surgery (EACTS). European Heart Journal 2018; 39(3): 213-260, doi: 10.1093/eurheartj/ehx419.

53. Kufner S., Sorges J., Mehilli J., Cassese S., Repp J., Wiebe J., Lohaus R., Lahmann A., Rheude T., Ibrahim T., Massberg S. Randomized trial of polymerfree sirolimus- and probucol-eluting stents versus durable polymer zotarolimus-eluting stents: 5-year results of the ISAR-TEST-5 trial. JACC Cardiovasc. Interv. 2016; 9(8): 784-792, doi: 10.1016/j.jcin.2016.01.009.

54. Yan B.P., Ajani A.E., New G., Duffy S.J., Farouque O., Shaw J., Sebastian M., Lew R., Brennan A., Andrianopoulos N., Reid C. et al. Are drug-eluting stents indicated in large coronary arteries? Insights from a multi-centre percutaneous coronary intervention registry. Int. J. Cardiol. 2008; 130(3): 374-379, doi: 10.1016/j.ijcard.2008.06.046.

55. Abe S., Sato A., Hoshi T., Maruta S. Drug-eluting versus bare-metal stents in large coronary arteries of patients with ST-segment elevation myocardial infarction: Findings from the ICAS registry. Journal of Cardiology 2014; 64(5): 377-383, doi: 10.1016/j.jjcc.2014.02.020.

56. Pfisterer M., Brunner-La Rocca H.P., Rickenbacher P., Hunziker P., Mueller C., Nietlispach F., Leibundgut G., Bader F., Kaiser C. Long-term benefit-risk balance of drug-eluting vs. bare-metal stents in daily practice: does stent diameter matter? Three-year follow-up of BASKET. European Heart Journal 2009; 30(1): 16-24, doi: 10.1093/eurheartj/ehn516.

57. Brunner-La Rocca H.P., Kaiser C., Pfisterer M. Targeted stent use in clinical practice based on evidence from the BAsel Stent Cost Effectiveness Trial (BASKET). Eur. Heart J. 2007; 28(6): 719-725, doi: 10.1093/eurheartj/ehl490. 58. Jeger R.V., Schneiter S., Kaiser C., Bonetti P.O., Brunner-La Rocca H., Handke M. Osswald S., Buser P.T., Pfisterer M.E. Drug-eluting stents compared with bare metal stents improve late outcome after saphenous vein graft but not after large native vessel interventions. Cardiology 2009; 112(1): 49-55, doi: 10.1159/000137699.

59. Menozzi A., Solinas E., Ortolani P., Repetto A., Saia F., Piovaccari G., Manari A., Magagnini E., Vignali L., Bonizzoni E., Angelica P. et al. Twenty-four month clinical outcomes of sirolimus-eluting stents for the treatment of small coronary arteries: the long-term SES-SMART clinical study. Eur. Heart J. 2009; 30(17): 2095-2101, doi: 10.1093/eurheartj/ehp224.

60. Rodriguez-Granillo G.A., Valgimigli M., Garcia-Garcia H.M., Ong A.T.L., Aoki J., Mieghem C.A.G., Tsuchida K., Sianos G., McFadden E., van der Giessen W.J. One-year clinical outcome after coronary stenting of very small vessels using $2.25 \mathrm{~mm}$ sirolimus- and paclitaxel-eluting stents: a comparison between the RESEARCH and T-SEARCH registries. J. Invasive Cardiol. 2005; 17(8): 409-412, PMID: 16079445.

61. Cortese B., Bertoletti A., De Matteis S., Danzi G.B., Kastrati A. Drug-eluting stents perform better than bare metal stents in small coronary vessels: a meta-analysis of randomised and observational clinical studies with mid-term follow up. Int. J. Cardiol. 2012; 161(2): 73-82, doi: 10.1016/j.ijcard.2011.04.016. 
62. Elezi S., Dibra A., Mehilli J.A., Pache J., Wessely R., Schömig A., Kastrati A. Vessel size and outcome after coronary drug-eluting stent placement: results from a large cohort of patients treated with sirolimus- or paclitaxel-eluting stents. J. Am. Coll. Cardiol. 2006; 48(7): 1304-1309, doi: 10.1016/j. jacc.2006.05.068

63. Mehilli J., Dibra A., Kastrati A., Pache J., Dirschinger J., Schömig A. Randomized trial of paclitaxel- and sirolimus-eluting stents in small coronary vessels. Eur Heart J. 2006; 27(3): 260-266, doi: 10.1093/eurheartj/ehi721. 64. Park K.H., Park S.W., Hong M.K., Kim Y.H., Lee B.K., Park D.W., Cho B.R., Kim M.J., Park K.M., Lee C.W., Cheong S.S. et al. Comparison of the effectiveness of sirolimus- and paclitaxel-eluting stents for small coronary artery lesions. Catheter Cardiovasc. Interv. 2006; 67(4): 589-594, doi: 10.1002 ccd. 20700

65. Schunkert H., Harrell L., Palacios I.F. Implications of small reference vessel diameter in patients undergoing percutaneous coronary revascularization. $\mathrm{J}$. Am. Coll. Cardiol. 1999; 34(1): 40-48, doi: 10.1016/s0735-1097(99)00181-3. 66. Elezi S., Kastratie A., Neumann F.J., Hadamitzky M., Dirschinger J., Schömig A. Vessel size and long-term outcome after coronary stent placement. Circulation 1998; 98(18): 1875-1880, doi: 10.1161/01.cir.98.18.1875.

67. Biondi-Zoccai G., Moretti C., Abbate A., Sheiban I. Percutaneous coronary intervention for small vessel coronary artery disease. Cardiovasc. Revasc. Med. 2010; 11(3): 189-198, doi: 10.1016/j.carrev.2009.04.007.

68. Akiyama T., Moussa I., Reimers B., Ferraro M., Kobayashi Y., Blengino S. Di Francesco L., Finci L., Di Mario C., Colombo A. Angiographic and clinical outcome following coronary stenting of small vessels: a comparison with coronary stenting of large vessels. J. Am. Coll. Cardiol. 1998; 32: 1610-1618, doi: 10.1016/S0735-1097(98)00444-6

69. Agostoni P., Biondi-Zoccai G.G., Gasparini G.L., Anselmi M., Morando G., Turri M., Abbate A., McFadden E.P., Vassanelli C., Zardini P., Colombo A., Serruys P.W. Is bare-metal stenting superior to balloon angioplasty for smal vessel coronary artery disease? Evidence from a meta-analysis of randomized trials. Eur. Heart J. 2005; 26(9): 881-889, doi: 10.1093/eurheartj/ehi116.

70. van der Heijden L.C., Kok M.M., Danse P.W., Schramm A.R., Hartmann M., Löwik M.M., Linssen G.C.M., Stoel M.G., Doggen C.J.M., von Birgelen C. Small-vessel treatment with contemporary newer-generation drug -eluting coronary stents in all-comers: Insights from 2-year DUTCH PEERS (TWENTE II) randomized trial. Am. Heart J. 2016; 176: 28-35, doi: 10.1016/j. ahj.2016.02.020.

71. Claessen B.E., Smits P.C., Kereiakes D.J., Parise H., Fahy M., Kedhi E., Serruys P.W., Lansky A.J., Cristea E., Sudhir K., Sood P. et al. Impact of Lesion Length and Vessel Size on Clinical Outcomes After Percutaneous Coronary Intervention With Everolimus- Versus Paclitaxel-Eluting Stents: Pooled Analysis From the SPIRIT (Clinical Evaluation of the XIENCE V Everolimus Eluting Coronary Stent System) and COMPARE (Second-generation everolimus-eluting and paclitaxel-eluting stents in real-life practice) Randomized Trials JACC: Cardiovascular Interventions 2011; 4(11): 1209-1215, doi: 10.1016/j. jcin.2011.07.016.

72. Buiten R.A., Ploumen E.H., Zocca P., Doggen C.J.M., van der Heijden L.C., Kok M.M., Danse P.W., Schotborgh C.E., Scholte M., de Man F.H., Linssen G.C.M., von Birgelen C. Outcomes in Patients Treated With Thin-Strut Very Thin-Strut, or Ultrathin-Strut Drug-Eluting Stents in Small Coronary Vessels: A Prespecified Analysis of the Randomized BIO-RESORT Trial. JAMA Cardiol. 2019; 4(7): 659-669, doi: 10.1001/jamacardio.2019.1776.

73. Iglesias J.F., Muller O., Heg D., Roffi M., Kurz D.J., Moarof I., Weilenmann D., Kaiser C., Tapponnier M., Stortecky S., Losdat S. et al. Biodegradable polymer sirolimus-eluting stents versus durable polymer everolimus-eluting stents in patients with ST-segment elevation myocardial infarction (BIOSTEMI): a single-blind, prospective, randomised superiority trial. Lancet 2019 394(10205): 1243-1253, doi: 10.1016/S0140-6736(19)31877-x.

74. Kandzari D.E., Koolen J.J., Doros G., Massaro J.J., Garcia-Garcia H.M., Bennett J., Roguin A., Gharib E.G., Cutlip D.E., Waksman R. Ultrathin Bioresorbable Polymer Sirolimus-Eluting Stents Versus Thin Durable Polymer Everolimus-Eluting Stents JACC 2018; 72(25): 3287-3297, doi: 10.1016/j. jacc.2018.09.019

75. Saito S., Toelg R., Witzenbichler B., Haude M., Masotti M., Salmeron R BIOFLOW-IV, a randomised, intercontinental, multicentre study to assess the safety and effectiveness of the Orsiro sirolimus-eluting stent in the treatment of subjects with de novo coronary artery lesions: primary outcome target vessel failure at 12 months. EuroIntervention 2019; 15(11): 1006-1013, doi: 10.4244/ eij-d-18-01214.

76. Iglesias J.F., Muller O., Heg D., Roffi M., Kurz D.J., Moarof I. Biodegradable polymer sirolimus-eluting stents versus durable polymer everolimus-eluting stents in patients with ST-segment elevation myocardial infarction (BIOSTEMI): a single-blind, prospective, randomised superiority trial. Lancet 2019; 394(10205): 1243-1253, doi: 10.1016/s0140-6736(19)31877-x.

77. Park D.W., Kim Y.H., Yun S.C., Ahn J.M., Lee J.Y., Kim W.J., Kang S.J., Lee S.W., Lee C.W., Park S.W., Park S.J. Frequency, causes, predictors, and clinical significance of peri-procedural myocardial infarction following percutaneous coronary intervention. European Heart Journal 2013; 34(22): 1662 -1669, doi: 10.1093/eurheartj/eht048.

78. Kawamoto H., Panoulas V.F., Sato K., Miyazaki T., Naganuma T., Sticchi A. et al. Impact of strut width in periprocedural myocardial infarction: a propensity-matched comparison between bioresorbable scaffolds and the first-generation sirolimus-eluting Stent. JACC: Cardiovasc. Interv. 2015; 8(7): 900-909, doi: 10.1016/j.jcin.2015.02.011.

79. Koskinas K.C., Chatzizisis Y.S., Antoniadis A.P., Giannoglou G.D. Role of endothelial shear stress in stent restenosis and thrombosis pathophysiologic mechanisms and implications for clinical translation. J. Am. College Cardiol. 2012; 59(15): 1337-1349, doi: 10.1016/j.jacc.2011.10.903.

80. Kitabata $\mathrm{H}$., Kubo $\mathrm{T}$. Komukai $\mathrm{K}$ et al. Effect of strut thickness on neointimal atherosclerotic change over an extended follow-up period. Am. Heart J. 2012; 163(4): 608-616, doi: 10.1016/j.ahj.2012.01.007.

81. Ng J., Bourantas C.V., Torii R., Ang H.Y., Tenekecioglu E., Serruys, P.W.Foin N. Local hemodynamic forces after stenting. Implications on restenosis and thrombosis. Arteriosclerosis, Thrombosis, and Vascular Biology 2017; 37: 2231-2242, doi: 10.1161/ATVBAHA.117.309728.

82. Wasilewski J., Osadnik T., Peryt-Stawiarska S., Poloński L. The role of haemodynamic factors in the development of in-stent restenosis. Polish Heart J. 2012; 70(11): 1194-1198. https://www.mp.pl/kardiologiapolska/en/node/ $11764 /$ pdf.

83. Fukumoto Y., Hiro T., Fujii T., Hashimoto G., Fujimura T., Yamada J., Okamura T., Matsuzaki M. Localized elevation of shear stress is related to coronary plaque rupture. A 3-dimensional intravascular ultrasound study with in-vivo color mapping of shear stress distribution. J. Am. Coll. Cardiol. 2008; 51(6): 645-650, doi: 10.1016/j.jacc.2007.10.030.

84. Serruys P.W., Chevalier B., Sotomi Y., Cequier A., Carrié D., Piek J.J., Van Boven A.J., Dominici M., Dudek D., McClean D., Helqvist S., Haude M. Comparison of an everolimus-eluting bioresorbable scaffold with an everolimus-eluting metallic stent for the treatment of coronary artery stenosis (ABSORB II). Lancet 2016; 388(10059): 2479-2491, doi: 10.1016/S01406736(16)32050-5.

85. Kereiakes D.J., Ellis S.G., Metzger C., Caputo R.P., Rizik D.G., Teirstein P.S., Litt M.R., Kini A., Kabour A., Marx S.O., Popma J.J et al 3-year clinical outcomes with everolimus-eluting bioresorbable coronary scaffolds: The ABSORB III Trial. J. Am. Coll. Cardiol. 2017; 70(23): 2852-2862, doi: 10.1016/j. jacc.2017.10.010.

86. Palmerini T., Benedetto U., Biondi-Zoccai G., Riva D.D., Bacchi-Reggiani L., Smits P.C., Vlachojannis G.J., Jensen L.O., Christiansen E.H., Berencsi K., Valgimigli M. et al. Long-Term Safety of Drug-Eluting and Bare-Metal Stents Evidence From a Comprehensive Network Meta-Analysis. J. Am. Coll. Cardiol. 2015; 65: 2496-2507, doi: 10.1016/j.jacc.2015.04.017.

87. Savvoulidis P., Perlman G., Bagur R. The EluNIRTM ridaforolimus eluting coronary stent system. Expert Rev. Med. Devices. 2019; 16(1): 71-76, doi: 10.1080/17434440.2018.1549986

88. Rapetto C., Leoncini M. Magmaris: a new generation metallic sirolimuseluting fully bioresorbable scaffold: present status and future perspectives. J. Thorac. Dis. 2017; 9(Suppl 9): 903-913, doi: 10.21037/jtd.2017.06.34

89. Verheye S., Ormiston J.A., Stewart J., Webster M., Sanidas E., Costa R., Costa Jr J.R., Chamie D., Abizaid A.S., Pinto I., Morrison L. et al. A nextgeneration bioresorbable coronary scaffold system: from bench to first clinical evaluation: 6- and 12-month clinical and multimodality imaging results. JACC Cardiovasc. Interv. 2014; 7(1): 89-99, doi: 10.1016/j.jcin.2013.07.007. 